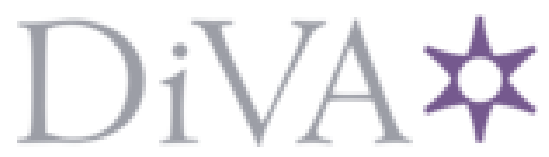

http://www.diva-portal.org

\title{
Postprint
}

This is the accepted version of a paper published in Biochemistry. This paper has been peer-reviewed but does not include the final publisher proof-corrections or journal pagination.

Citation for the original published paper (version of record):

Chi, C., Haq, S., Rinaldo, S., Dogan, J., Cutruzzolà, F. et al. (2012)

Interactions outside the boundaries of the canonical binding groove of a pdz domain influence ligand binding.

Biochemistry, 51(44): 8971-8979

http://dx.doi.org/10.1021/bi300792h

Access to the published version may require subscription.

N.B. When citing this work, cite the original published paper.

Permanent link to this version:

http://urn.kb.se/resolve?urn=urn:nbn:se:uu:diva- 186213 


\section{Interactions outside the boundaries of the canonical binding groove of a PDZ domain influence ligand binding}

This work was supported by the Swedish Research Council (to PJ and PL), Lars Hiertas Minne and the Royal Swedish society (to $\mathrm{CNC}$ ), the Italian Ministero dell'Istruzione dell'Universita`e della Ricerca, Progetto di Interesse 'Invecchiamento' (to SG), the Ministero dell'Istruzione, Università e Ricerca of Italy (RBRN07BMCT_007) (to FC) and from the Sapienza University of Rome (Italy) (to $\mathrm{FC})$.

Celestine N. Chi ${ }^{1}$, S. Raza Haq ${ }^{1}$, Serena Rinaldo ${ }^{2}$, Jakob Dogan ${ }^{1}$, Francesca Cutruzzolà $^{2}$, Åke Engström ${ }^{1}$, Stefano Gianni ${ }^{3}$, Patrik Lundström ${ }^{4 *}$, and Per Jemth ${ }^{1^{*}}$

${ }^{1}$ Department of Medical Biochemistry and Microbiology, Uppsala University, BMC Box 582, SE-75123 Uppsala, Sweden.

${ }^{2}$ Istituto Pasteur -Fondazione Cenci Bolognetti, Dipartimento di Scienze Biochimiche "A. Rossi Fanelli", Sapienza Università di Roma, Piazzale A. Moro 5, 00185 Rome, Italy

${ }^{3}$ Istituto Pasteur -Fondazione Cenci Bolognetti and Istituto di Biologia e Patologia Molecolari del CNR, Dipartimento di Scienze Biochimiche "A. Rossi Fanelli", Sapienza Università di Roma, Piazzale A. Moro 5, 00185 Rome, Italy 
${ }^{4}$ Division of Molecular Biotechnology, Department of Physics, Chemistry and Biology, Linköping University, SE-58183, Linköping, Sweden.

*Corresponding author: patlu@ifm.liu.se; phone: +46-13-286 650

*Corresponding author: per.jemth@imbim.uu.se; phone: +46-18-471 4557 


\section{Abbreviations}

ITC, isothermal titration calorimetry; PDZ, Postsynaptic density protein-95/Discs large/Zonula Occludens-1; PSD-95, Postsynaptic density protein-95 


\section{ABSTRACT}

The PDZ domain is a protein-protein interaction module with a shallow binding groove where protein ligands bind. However, interactions that are not part of this canonical binding groove are likely to modulate peptide binding. We have investigated such interactions beyond the binding groove for PDZ3 from PSD-95 and a peptide derived from the C-terminus of the natural ligand CRIPT. We found by NMR experiments that up to eight residues of the peptide ligand interact with the PDZ domain, showing that the interaction surface extends far outside of the binding groove as defined by the crystal structure. PDZ3 contains an extra structural element, a C-terminal helix ( $\alpha 3)$, which is known to affect affinity. Deletion of this helix resulted in loss of several inter-molecular NOEs from peptide residues outside of the binding pocket, suggesting that $\alpha 3$ forms part of the extra binding surface in wild type PDZ3. Site-directed mutagenesis, isothermal titration calorimetry and fluorescence intensity experiments confirmed the importance of both $\alpha 3$ and the $\mathrm{N}$-terminal part of the peptide for the affinity. Our data suggest a general mechanism where different binding surfaces outside of the PDZ binding groove could provide sites for specific interactions. 
Postsynaptic density protein-95/Discs large/Zonula Occludens-1 (PDZ) domains are usually part of multi-domain proteins and coordinate signaling and scaffolding by binding and organizing various cellular proteins. ${ }^{1-5}$ They generally bind to short Cterminal sequences in a well-defined binding groove. ${ }^{6}$ There are multiple PDZ domains within the same cell and most likely several competing protein ligands present within the vicinity of each PDZ domain. In crystal or NMR structures of PDZ domains and peptide ligands, usually only four-five ligand residues are visible. Thus, to achieve selectivity towards ligands in a cellular context, other factors than the interactions in the binding groove are likely to play a role. Compartmentalization, local concentration ${ }^{7,8}$ and allosteric effects ${ }^{9,10}$ have been proposed as means by which PDZ domains modulate selectivity towards their binding partners.

However, structural elements located outside of the canonical PDZ fold may also influence affinity and specificity. For example, the src homology 3 (SH3) domain modulates the affinity of the adjacent MAGI1 PDZ3. ${ }^{11,12}$ Another example is the third PDZ domain of PSD-95 (PDZ3), which contains an $\alpha$ helix located at the C-terminus outside of the canonical PDZ fold ${ }^{13}$ (Fig. 1). This helix is referred to as $\alpha 3$ and it curls towards the ligand-binding groove between $\alpha 2$ and $\beta 2$ of PSD-95 PDZ3. The $\alpha 3$ helix is however located more than $5 \AA$ from the last residue that is visible in the crystal structure $\left(\mathrm{Gln}_{-3}\right)$ of the complex between PDZ3 and peptide ligand. ${ }^{13}$ The $\alpha 3$ thus appears not to interact with the ligand. Nevertheless, deletion of the $\alpha 3$ helix has a profound effect on the affinity between PDZ3 and peptide ligand and this helix was suggested to regulate a hidden allostery. ${ }^{14}$ Although the peptide ligand residue $\mathrm{Tyr}_{-5}$ is not visible in the crystal structure of PDZ3, it contributes to the affinity since its 
deletion results in a 24-fold decrease in affinity as measured by isothermal titration calorimetry (ITC). ${ }^{15}$ It is possible that $\mathrm{Tyr}_{-5}$ interacts transiently with PDZ3, via the $\alpha 3$ helix or other parts of the PDZ domain. The presence of such very short-lived interactions may have implications for the whole family of PDZ domains and their interactions with protein ligands.

To test this hypothesis and learn more about interactions outside of the binding groove of PDZ domains, we investigated the role of peptide residues outside of the binding pocket as well as the $\alpha 3$ helix in PDZ3 by protein engineering in conjunction with NMR, ITC and kinetic experiments based on fluorescence. We demonstrate that binding is indeed modulated by interactions beyond the canonical binding groove.

\section{MATERIALS AND METHODS}

Expression and purification of PDZ variants. The PDZ domain used in this study was PDZ3 from human PSD-95 and it contains the mutation F337W (this construct is hereafter referred to as PDZ3). The numbering of residues refers to full length PSD$95 \alpha$ without exon $\mathrm{b}$ and is the same as used in Doyle et al. ${ }^{13}$ The F337W mutation serves as a fluorescence probe in ligand binding experiments and does not affect the affinity of the PDZ3-peptide interaction. ${ }^{16-18}$ It also does not affect the energetic coupling pattern between side-chain residues in the PDZ domain and in the peptide ligand ${ }^{9}$, since the coupling energy for F337W is zero with regard to a second mutation in the peptide ligand, either at the C-terminal $\mathrm{Val}_{0}$ or at $\mathrm{Ser}_{-2}$ (not shown). The sequence corresponding to the $\alpha 3$-helix (residues 396-401) was deleted from the 
cDNA of PDZ3 to generate the $\alpha 3$-helix-deleted mutant PDZ3 $\Delta \alpha 3$. The point mutants Y397E, R399A and F400A in the $\alpha 3$-helix were created by inverted PCR on the cDNA encoding PDZ3, using Pfu Turbo polymerase (Stratagene).

Transformed E. coli BL21 DE3 pLysS cells were selected by growing in a 2TY medium containing ampicillin $(50 \mu \mathrm{g} / \mathrm{ml})$ and chloramphenicol $(35 \mu \mathrm{g} / \mathrm{ml})$ at $37^{\circ} \mathrm{C}$ until the $\mathrm{OD}_{600}$ was $0.4-0.6$. Protein expression was induced by adding $1 \mathrm{mM}$ isopropyl- $\beta$-D-thiogalactopyranoside and the cells were allowed to express protein overnight at $30^{\circ} \mathrm{C}$. The cells were collected by centrifugation (7000 $\mathrm{g}$ for $\left.10 \mathrm{~min}\right)$ and re-suspended in buffer $(50 \mathrm{mM}$ Tris/ $\mathrm{HCl}, \mathrm{pH} 8.5,400 \mathrm{mM} \mathrm{NaCl})$. The cells were then disrupted by ultra-sonication, followed by centrifugation $(35000 \mathrm{~g})$ for 1 hour. The supernatant thus obtained was filtered successively through 0.45 and $0.2 \mu \mathrm{m}$ filters (Sarstedt). The filtered supernatant was loaded onto a Nickel (II)-charged chelating Sepharose FF column (GE healthcare), equilibrated with $50 \mathrm{mM}$ Tris/HCl pH 8.5, 400 $\mathrm{mM} \mathrm{NaCl}$ and washed with $300 \mathrm{ml}$ of the same buffer. The bound protein was eluted with $250 \mathrm{mM}$ imidazole $\mathrm{pH}$ 7.9. The fractions containing the PDZ were pooled, concentrated and dialyzed overnight against $50 \mathrm{mM}$ Tris/ $\mathrm{HCl}, \mathrm{pH} 8.5$. The dialyzed protein samples were filtered through $0.2 \mu \mathrm{m}$ filters and loaded onto a Q-column (GE Healthcare), equilibrated with $50 \mathrm{mM}$ Tris/ $\mathrm{HCl}, \mathrm{pH}$ 8.5. The protein did not bind to the column and appears in the un-bound fraction. The fraction containing the protein was run on an S-column (GE Healthcare), equilibrated with $50 \mathrm{mM}$ Tris/HCl, $\mathrm{pH}$ 8.5. The bound protein was eluted with a gradient of $0-1 \mathrm{M} \mathrm{NaCl}$ in $50 \mathrm{mM}$ Tris/ $\mathrm{HCl}, \mathrm{pH}$ 8.5. The fractions containing the PDZ were pooled and the purity of the PDZ variants were checked by SDS-PAGE stained with coomassie brilliant blue and the identity of the mutants were confirmed by MALDI-TOF mass spectrometry. Purified mutants 
were analyzed by urea denaturation experiments. We observed the typical sigmoidal denaturation curve for the point mutants (not shown), which, together with the fact that they bound peptide ligand, confirmed that they were properly folded.

Peptide ligands. For ITC binding experiments the peptides KQTSV and YKQTSV (GL Biochem, Shanghai) corresponding to the five or six last residues of CRIPT was used. A dansylated version of the longer peptide, D-YKQTSV, was used in stopped flow experiments. Numbering of the peptide ligand is as in Figure 1, with the Cterminal residue numbered 0 and subsequent residues $-1,-2$ etc towards the $\mathrm{N}$ terminus. For the NMR measurements a longer version of the CRIPT C-terminus ${ }^{19}$ was expressed as a double-labeled ${ }^{15} \mathrm{~N}^{13} \mathrm{C}$ lipoyl fusion protein in $E$ coli. The lipoylpeptide fusion protein was loaded onto a nickel column, washed with $50 \mathrm{mM}$ Tris/HCl, $\mathrm{pH} 8.5,400 \mathrm{mM} \mathrm{NaCl}$ and subsequently eluted with $250 \mathrm{mM}$ imidazole, $\mathrm{pH}$ 7.9. Fractions containing lipoyl-peptide were then pooled, filtered with a $0.2 \mu \mathrm{m}$ filter and loaded onto a Q-column equilibrated with $50 \mathrm{mM}$ Tris/HCl, $\mathrm{pH}$ 8.5. Pure lipoylpeptide was eluted by a gradient of $0-500 \mathrm{mM} \mathrm{NaCl}$ in $50 \mathrm{mM}$ Tris/HCl, $\mathrm{pH}$ 8.5. The peptide was cleaved off from the fusion protein with thrombin and then purified by reversed phase HPLC on a $\mathrm{C} 18$ column, lyophilized and stored at $-20^{\circ} \mathrm{C}$. The peptide contained two extra residues at the N-terminus, GS, from the thrombin cleavage site, thus resulting in the following peptide: GSKNYKQTSV. The identity was confirmed by MALDI-TOF mass spectrometry. Prior to NMR experiments, the peptide was dissolved in the appropriate buffer and its concentration was determined by UV absorbance using a calculated extinction coefficient of $1490 \mathrm{~cm}^{-1} \mathrm{M}^{-1}$. 
NMR titrations. Titration experiments were performed on a Varian INOVA 600 $\mathrm{MHz}$ spectrometer equipped with a cryogenically cooled probe, at $283 \mathrm{~K}$ and $277 \mathrm{~K}$. Peptide samples were dissolved in $50 \mathrm{mM}$ potassium phosphate, $\mathrm{pH} 7.5,10 \% \mathrm{D}_{2} \mathrm{O}$ and ${ }^{1} \mathrm{H}-{ }^{15} \mathrm{~N}$ HSQC spectra for peptide $(290 \mu \mathrm{M}$ or $150 \mu \mathrm{M})$ were recorded at an increasing concentration of unlabeled $\operatorname{PDZ3}(0,260,270,310,370 \mu \mathrm{M}$, respectively) or unlabeled PDZ3 $\Delta \alpha 3(0,520,820,940 \mu \mathrm{M}$, respectively). For backbone resonance assignments, ${ }^{15} \mathrm{~N}$ NOESY-HSQC, ${ }^{15} \mathrm{~N}$ TOCSY-HSQC, HNCACB, CBCA(CO)NH, $\mathrm{HN}(\mathrm{CA}) \mathrm{CO}$, and $\mathrm{HNCO}$ spectra were recorded for the bound/unbound peptide. Aliphatic side-chain resonance assignments were obtained using HCCH-TOCSY and ${ }^{13} \mathrm{C}$ NOESY-HSQC experiments. The aromatic side-chain of $\mathrm{Tyr}_{-5}$ was assigned using ${ }^{13} \mathrm{C}$ edited NOESY spectra optimized for the aromatic resonances. ${ }^{13} \mathrm{C}$ edited NOESY experiments were used to detect inter/intra molecular NOEs. Data processing and analysis were done with NMRpipe ${ }^{20}$ and Sparky (Goddard and Kneller, SPARKY 3, University of California, San Francisco), respectively.

Stopped-flow experiments. Pre-equilibrium ligand binding experiments were performed on an SX-20 MV stopped-flow spectrometer (Applied photophysics, Leatherhead, UK). For $k_{o n}$ measurements, the concentration of protein (PDZ3, PDZ3 $\Delta \alpha 3$ and point mutants Y397E, R399A and F400A) was kept constant at $3 \mu \mathrm{M}$ and the concentration of D-YKQTSV peptide was varied. The experiments were performed at $10^{\circ} \mathrm{C}$ in $50 \mathrm{mM}$ potassium phosphate $\mathrm{pH}$ 7.5. Excitation of the $\operatorname{Trp}_{337}$ was carried out at $280 \mathrm{~nm}$ while the emission was recorded using a $330 \mathrm{~nm}$ band-pass filter. Traces obtained from pre-equilibrium ligand binding were fitted to a single exponential function (Eq. 1). 
$A=\Delta A_{E Q}\left(1-e^{-k o b s . t}\right)+C$

$A$ is the change in florescence over time $t$ and $k_{o b s}$ is the observed rate constant. The $k_{o b s}$ values were plotted against the peptide concentration and fitted to Eq. 2.

$k_{\text {obs }}=\left(k_{o n}^{2}\left(n-[A]_{0}\right)^{2}+k_{o f f}^{2}+2 k_{o n} k_{o f f}\left(n+[A]_{0}\right)\right)^{0.5}$

where $k_{o n}$ is the association or on-rate constant and $k_{\text {off }}$ is the dissociation or off-rate constant. $[A]_{0}$ and $n$ are the total concentrations of peptide and protein (held constant at $3 \mu \mathrm{M})$, respectively. ${ }^{21}$

The off-rate constant was measured separately for PDZ3, PDZ3 $\Delta \alpha 3$ and point mutants Y397E, R399A and F400A. For these experiments protein $(3 \mu \mathrm{M})$ was pre-incubated with the D-YKQTSV peptide $(3 \mu \mathrm{M})$. The complex was dissociated with the addition of unlabeled YKQTSV peptide and the resulting traces were fitted to Eq. 1. $k_{o b s}$ values thus obtained were plotted against the concentration of unlabeled peptide and fitted to Eq. 3.

$k_{o b s}=k_{o f f}+k_{o n}{ }^{\prime}\left(K_{D} /\left(K_{D}+n\right)\right)$

(Eq. 3)

where $n$ is the concentration of unlabeled peptide, $K_{D}$ is the equilibrium dissociation constant for the unlabeled peptide and the PDZ, and $k_{\text {on }}{ }^{\prime}$ is the apparent (first order) on-rate constant for the PDZ and the dansylated peptide at the particular concentration of peptide in the experiment. At high $n$, the observed rate constant $k_{\text {obs }}$ approaches the dissociation rate constant $k_{\text {off }}$, which is well determined in the curve fitting. 
Eq. 4 was used to determine the change in binding free energy of PDZ-peptide interaction upon mutation, $\Delta \Delta G$, in Table 1 .

$\Delta \Delta G=R T \times \ln \left(\left(k_{o f f}^{W T} k_{o n}{ }^{m u t}\right) /\left(k_{o f f}{ }^{m u t} k_{o n}{ }^{W T}\right)\right)$

$R$ is the gas constant and $T$ is the temperature in Kelvin.

Competition ligand binding experiments. To estimate $K_{D}$ values of YKQTSV and KQTSV, competition ligand binding experiments were performed in the SX-20 MV stopped-flow spectrometer in $50 \mathrm{mM}$ potassium phosphate $\mathrm{pH} 7.5$ at $10^{\circ} \mathrm{C}$. For the measurements, a complex formed by pre-incubating 2 or $3 \mu \mathrm{M}$ protein (either PDZ3 or PDZ3 $\Delta \alpha 3$ ) with 4 or $6 \mu \mathrm{M}$ D-YKQTSV peptide, respectively, was dissociated with different concentrations of the non-dansylated peptide (either YKQTSV or KQTSV). The resulting change in the dansyl fluorescence was monitored and plotted versus peptide concentration. Excitation was done at $280 \mathrm{~nm}$ (excitation of the $\operatorname{Trp}_{337}$ ) while the emission was recorded using a $330 \mathrm{~nm}$ band-pass filter in the stopped flow. Data from the competition ligand binding were fitted to Eq. $5 .{ }^{18}$

$F=\left[\left(K_{D 1}+K_{D 1}\left[L_{2}\right] / K_{D 2}+[P]_{t}+\left[L_{1}\right]_{t}\right) / 2-\left(\left(K_{D 1}+K_{D 1}\left[L_{2}\right] / K_{D 2}+[P]_{t}+\left[L_{1}\right]_{t}\right)^{2} / 4-\right.\right.$ $\left.\left.[P]_{t}\left[L_{1}\right]_{t}\right)^{0.5}\right] \times B+C$

$F$ is the observed fluorescence signal at equilibrium, $K_{D 1}$ and $K_{D 2}$ are the dissociation constants of $L_{1}$ and $L_{2}$ respectively. $\left[L_{1}\right]_{t}$ is the total concentration of the D-YKQTSV peptide that was held constant at 4 or $6 \mu \mathrm{M}$ while $L_{2}$ is either YKQTSV or KQTSV peptide whose concentration was varied between $0-100 \mu \mathrm{M}$ and 0-470 $\mu \mathrm{M}$, 
respectively. $[P]_{t}$ is the total concentration of either PDZ3 or PDZ3 $\Delta \alpha 3$ held constant at 2 or $3 \mu \mathrm{M}$. $B$ is the total fluorescence change and $C$ is the end point. The $K_{D I}$ value for the dansylated peptide for PDZ3 and PDZ3 $\Delta \alpha 3$, respectively, was calculated from the ratio of $k_{\text {off }}$ and $k_{\text {on }}$ (Table 1) and used in Eq. 5. The $K_{D 2}$ values for YKQTSV and KQTSV are reported in the legend to Fig. 6.

Isothermal titration calorimetry (ITC) experiments. ITC experiments were carried out in an ITC200 microcalorimeter with a $200 \mu \mathrm{l}$ cell volume (GE healthcare). PDZ solution dialyzed in $50 \mathrm{mM}$ potassium phosphate $\mathrm{pH} 7.5$ was placed in the sample cell. Peptide stock was prepared in $50 \mathrm{mM}$ potassium phosphate, $\mathrm{pH} 7.5$ and aliquots of $1.5 \mu \mathrm{l}(0.12-0.24 \mathrm{mM}$ for YKQTSV and $0.24-1 \mathrm{mM}$ for KQTSV) were injected into the cell containing either PDZ3 $(8-13 \mu \mathrm{M})$ or PDZ3 $\Delta \alpha 3(15 \mu \mathrm{M})$ protein solution at $25^{\circ} \mathrm{C}$. Once the titration was completed, the raw data were then fitted using the "one-binding-site model" of the MicroCal version of ORIGIN. Experiments were performed in duplicate or in triplicate (for the wild type and mutant proteins, respectively). As a control, the heat exchange of peptide dilution into buffer has been measured and taken into account in data analysis. In our experiments, although the baseline is a little noisy, as expected for a highly sensitive instrument, the reproducibility is very good as shown by the low experimental errors given in Table 2 . Therefore, although the c value is slightly low, ${ }^{22}$ in particular for the mutant, the curve is not too shallow and is completed in a single experiment. The heat of binding $(\Delta \mathrm{H})$, the stoichiometry (n), and the dissociation constant $K_{D}$ were then calculated from plots of the heat evolved per mole of ligand injected versus the molar ratio of ligand to protein using the software provided by the manufacturer. 


\section{RESULTS}

First we performed NMR experiments to see which peptide ligand residues that interact with the protein. Next, in order to determine the contribution to the binding free energy of the $\alpha 3$ helix to PDZ3-peptide complex formation, we performed equilibrium and pre-equilibrium binding experiments with peptide ligand and wild type or mutant PDZ3.

At least eight peptide residues interact with PDZ3. In order to determine which residues in the peptide that likely interacts with PDZ3, we monitored chemical shift changes in ${ }^{1} \mathrm{H}^{15}{ }^{\mathrm{N}} \mathrm{HSQC}$ and ${ }^{1} \mathrm{H}-{ }^{13} \mathrm{C}$ HSQC experiments of a fully labeled peptide $(290 \mu \mathrm{M}$ or $150 \mu \mathrm{M})$ with saturating amounts of PDZ3 $(520 \mu \mathrm{M})$ and a variant where the $\alpha 3$ helix was removed, PDZ3 $\Delta \alpha 3(940 \mu \mathrm{M})$, respectively. The chemical shifts were assigned for free and bound peptide. In the free peptide eight of the resonances were observed at $277 \mathrm{~K}$ and six of the resonances were observed at $283 \mathrm{~K}$ (Fig. 2). The discrepancy is likely due to higher amide proton exchange rate with solvent at the higher temperature. In the bound form the backbone ${ }^{1} \mathrm{H}-{ }^{15} \mathrm{~N}$ resonances of eight residues (Fig. 2A) and the ${ }^{1} \mathrm{H}_{-}{ }^{13} \mathrm{C}$ resonances of the side chains of all residues (data not shown) were observed and assigned with the exception of $\mathrm{CB}$ of $\mathrm{Thr}_{-2}$ for peptide bound to PDZ3 $\Delta \alpha 3 .{ }^{1} \mathrm{H}-{ }^{13} \mathrm{C}$ and ${ }^{1} \mathrm{H}-{ }^{15} \mathrm{~N}$ combined chemical shift perturbations upon binding (CSP) were observed throughout the peptide except for Gly-9 both for the backbone and side chain residues showing that most of the peptide experiences significant changes in the environment on interaction with the protein (Fig. 3). However, our data cannot be used to conclusively state that all residues of the peptide 
are interacting with the PDZ domain since CSPs for residues that do not interact can be the result of conformational changes of the peptide itself due to interaction with PDZ3 in another part of the peptide. It is however noteworthy that the CSPs, for residues Lys -7 to $\mathrm{Gln}_{-3}$, differ significantly for binding to PDZ3 and PDZ3 $\Delta \alpha 3$. It is therefore tempting to speculate that these residues interact differently with the two forms of the PDZ domain and that the $\alpha 3$ helix is involved in the binding to wild type PDZ3.

In the crystal structure (pdb code: 1BE9) of PDZ3 in complex with the peptide TKNYKQTSV the motif closest to the N-terminus of the peptide is the $\alpha 3$, which is 5 $\AA$ away from the peptide residue $\mathrm{Gln}_{-3}$. No electron density was observed for the residues TKNYK in the N-terminus of the peptide. ${ }^{13}$ However, in the crystal structure of PDZ3 in complex with another peptide, KKETPV (pdb code: 1TP3) Lys -4 is about $4 \AA$ from the side-chain His $_{372}$. In order to see if the combined chemical shifts observed were due to direct interaction with the protein or if they were merely due to titration perturbation (upon addition of PDZ3), we performed NOESY-HSQC and HCCH-TOCSY experiments of the peptide in complex with PDZ3 and PDZ3 $\Delta \alpha 3$, respectively. By identifying peaks present in the NOESY-HSQC but absent in the HCCH-TOCSY spectra, we observed several NOEs (Fig. 4) between the respective protein and the peptide backbone and side chain residues from position 0 to -6 .

To further rule out the possibility that NOEs identified as inter-molecular were in fact not intra-molecular, we carefully checked the NOESY spectra for candidates with matching chemical shifts and confirmed that corresponding peaks were absent (Fig.4, panel V). Importantly, the inter-molecular NOEs obtained with the wild-type PDZ3 
were different from those with $\operatorname{PDZ} 3 \Delta \alpha 3$, demonstrating that the peptide form distinct transient interactions in the two cases and suggesting that the $\alpha 3$-helix may interact directly with the peptide ligand. To prove the latter hypothesis we would however need to perform the reverse experiment, i.e. to use isotopically labeled PDZ domain and determine which of its nuclei that interact with the peptide in NOESY experiments. Admittedly, the sensitivity is poor in all NOESY experiments due to low concentration and low temperature, especially experiments involving peptide bound to $\operatorname{PDZ3} \Delta \alpha 3$. Thus, we likely observed too few rather than too many intermolecular contacts.

In a previous study where the influence of the $\alpha 3$-helix of PDZ3 binding was investigated, the authors concluded that $\alpha 3$ modulates PDZ3 binding through entropy driven dynamic allostery rather than direct interactions. ${ }^{14}$ They did not detect any significant chemical shift changes for peptide residues other than 0 to -3 using natural abundance ${ }^{1} \mathrm{H}-{ }^{13} \mathrm{C}$ HSQC spectra recorded at $298 \mathrm{~K}$ (Fig. 6 of ref. ${ }^{14}$.) Furthermore, the concentration dependence of the chemical shift changes of these nuclei in these residues suggests exchange in the fast regime. However, in the present work we used a fully ${ }^{13} \mathrm{C}-{ }^{15} \mathrm{~N}$ labeled peptide and saturating concentration of protein and recorded our data at 277 and $283 \mathrm{~K}$ using a slightly different form of the peptide. As noted during our NMR titrations, at $89 \%$ saturation, most residues were in slow exchange and appeared as double peaks (14 in total) in the HSQC (Fig. 2B). Complete perturbation was observed only at $99 \%$ saturation, which could explain the discrepancy regarding the number of peptide residues making direct contact to the protein (the previous data was for 15\% molar ratio) (Fig. 2B). In addition, Petit et al. used a peptide with slightly different sequence in the N-terminus and including N- 
acetylation, which was previously shown to reduce the affinity for peptide-PDZ3 interactions. $^{15}$

\section{Deletion of the $\alpha 3$ helix and Tyr $_{-5}$ both induce a favorable entropy of binding. To} analyze the thermodynamics of the PDZ-peptide interaction and in particular the role of $\mathrm{Tyr}_{-5}$, since this peptide residue may interact with $\alpha 3$, we performed ITC experiments for both PDZ3 and PDZ3 $\Delta \alpha 3$ with two peptides, KQTSV and YKQTSV (Fig. 5). The fitted parameters from three of these four separate experiments are summarized in Table 2. PDZ3 interacts with the peptide YKQTSV with a highly favorable enthalpy $(\Delta H=-10 \mathrm{kcal} / \mathrm{mol})$ and slightly unfavorable entropy $(-T \Delta S=1.9$ $\mathrm{kcal} / \mathrm{mol}$ ). On deletion of the $\mathrm{Tyr}_{-5}$ in the peptide, the enthalpy of binding was reduced to $-4 \mathrm{kcal} / \mathrm{mol}$ and this was associated with a favorable entropic term $(-T \Delta S=-3.8$ $\mathrm{kcal} / \mathrm{mol}$ ). This result is similar to that when the $\alpha 3$ helix was deleted from PDZ3 ( $\Delta H$ $=-3.4 \mathrm{kcal} / \mathrm{mol}$ and $-T \Delta S=-3.7 \mathrm{kcal} / \mathrm{mol}$ ). Unfortunately, we did not see any heat change when both the $\alpha 3$ helix and $\mathrm{Tyr}_{-5}$ were deleted (data not shown). The likely reason for this is a low affinity between PDZ3 $\Delta \alpha 3$ and KQTSV, rather than a low enthalpic term, or possibly a combination of the two. Nonetheless, the short peptide was found to bind PDZ3 $\Delta \alpha 3$ in a competition assay (Fig. 6). We attempted to directly demonstrate an interaction between the $\alpha 3$-helix and $\mathrm{Tyr}_{-5}$ through a double mutant cycle (Fig. 6) but the error in $K_{\mathrm{D}}$ for the interaction between PDZ3 $\Delta \alpha 3$ and KQTSV was too large, due to the low affinity, which precluded a reliable quantitative analysis of the coupling energy.

Single point mutants in $\alpha 3$ destabilize the PDZ3-peptide complex. The results thus far suggested that residues $\mathrm{Val}_{0}$ to $\mathrm{Lys}_{-7}$ in the peptide are involved in complex 
formation and that $\alpha 3$ in PDZ3 increases the affinity. We therefore tested which individual side-chain residues in the $\alpha 3$ helix that contribute to binary complex formation, by making the following point mutants in the $\alpha 3$ helix: Y397E (a phosphorylation mimic ${ }^{23}$ ), and the deletion mutations R399A and F400A. The sidechains of these residues point towards the peptide binding groove and may interact with a bound peptide. The point mutants as well as the wild-type and PDZ3 $\Delta \alpha 3$ were subjected to presteady-state binding experiments (Fig. 7, Table 1). The $k_{\text {off }}$ for the interaction between the mutants, Y397E, R399A and F400A, with dansylated peptide, D-YKQTSV increased by factors of 26, 4 and 30, respectively, showing that these residues contribute significantly to the binding of the dansylated peptide ligand (Table 1). It is therefore likely that these side-chains will contribute to binding of natural ligands, either through direct and transient interactions or indirectly by stabilizing the $\alpha 3$ helix. $^{24}$

\section{DISCUSSION}

The binding energy in the interaction between PDZ domains and their ligands comes mainly from hydrophobic interactions and hydrogen bonds in the canonical binding groove. $^{13,15}$ But, since the PDZ domain ligand is often very flexible, it has the possibility to wrap around the surface of the PDZ to make additional favorable interactions outside of the canonical binding groove. This binding groove is typically occupied by only four ligand residues, as defined by hydrogen bonds between backbones of the peptide and the second $\beta$-strand of the PDZ domain (see Fig. 1). 
The contribution to the binding free energy of the PDZ3-peptide interaction by residues in the peptide ligand other than the four at the C-terminus was thoroughly investigated by Saro et al. using ITC. ${ }^{15}$ Their results showed that residues 0 to -5 (See Fig. 1) are important for PDZ3-peptide affinity, while further addition had minimal effect on the thermodynamics of binding. For example, the presence of $\mathrm{Tyr}_{-5}$ was found to increase the affinity 10 -fold at $\mathrm{pH}$ 6.0. Our data further confirm the importance of $\mathrm{Tyr}_{-5}$ in the PDZ3-peptide interaction. However, we also showed that residues -4 to -8 show changes in chemical shift upon binding, although the net energetic contribution of residues -6 to -8 to the affinity is low. Nonetheless, it is clear from our data that the N-terminal regions of long C-termini of PDZ ligands may explore a large binding surface outside of the peptide-binding groove.

All residues in the vicinity of the binding groove may afford such an extra binding surface, but the $\alpha 3$-helix in PDZ3 is particularly interesting in this respect since it is a so-called non-canonical structural element ${ }^{25,26}$ only found in some PDZ domains and for example not in the other two PDZ domains of PSD-95. Our ITC data suggest that the $\alpha 3$-helix in PDZ3 contributes a binding free energy for the CRIPT ligand of approximately $1.1 \mathrm{kcal} \mathrm{mol}^{-1}$, and the fluorescence based binding data give free energies of $2.4 \mathrm{kcal} / \mathrm{mol}$ (dansylated peptide) and $2.2 \mathrm{kcal} / \mathrm{mol}$ (Fig. 6, large error), in qualitative agreement with published data on a longer peptide $(1.8 \mathrm{kcal} / \mathrm{mol}){ }^{14}$ Moreover, we detected inter-molecular NOEs between the PDZ3 and $\mathrm{Tyr}_{-5}$ of the peptide. The absence of these inter-molecular NOEs in experiments with labeled peptide and PDZ3 $\Delta \alpha 3$, indicates that the $\alpha 3$-helix may in fact be involved in direct short-lived interactions with peptide ligand side-chains although it remains to be proved. 
The point mutations in $\alpha 3$ further demonstrate the importance of this helix. A recent computational study by Mostarda et al. ${ }^{24}$ shed light on the destabilizing effects of the mutations. They found by molecular dynamics simulations that $\mathrm{Tyr}_{397}$ and $\mathrm{Phe}_{400}$ make stabilizing hydrophobic interactions with each other and with residues in PDZ3, $\operatorname{Arg}_{399}$ makes a transient salt bridge with $\mathrm{Glu}_{334}$, which in turn stabilizes the $\beta 2-\beta 3$ loop, and $\mathrm{Glu}_{401}$ interacts with Lys 355 . Thus, mutation of these residues (as well as the complete removal of $\alpha 3$ ) might influence binding indirectly by destabilization of a pre-organized binding site for the peptide. But, they also observed transient salt bridges between $\mathrm{Glu}_{331}$ and $\mathrm{Asp}_{332}$ in PDZ3 and Lys-4 and Lys-7 in the CRIPT peptide, along with unstable hydrophobic contacts between the peptide and $\alpha 3$. The E331A mutation indeed results in both a decreased $k_{\text {on }}$ and an increased $k_{\text {off. }}{ }^{9}$ Thus, simulation $^{24}$ and experiment conspire to reveal a protein-ligand interaction for PDZ3 governed by $(i)$ stable interactions $\left(t_{1 / 2} \sim 1 / k_{\text {off }}\right)$ in the canonical binding site ${ }^{9,13,15}$, (ii) transient $\left(t_{1 / 2}<<1 / k_{\text {off }}\right)$ but direct interactions outside of this binding site involving for example Glu $\mathrm{u}_{331}$ and most likely portions of $\alpha 3$, and (iii) long-range interactions. ${ }^{9,14,17}$

The additional C-terminal extension is not unique for PDZ3. ${ }^{25,26}$ In MAGI PDZ1 for example, an extended C-terminal loop makes direct interactions with $\mathrm{Arg}_{-4}, \mathrm{Arg}_{-5}$ and $\mathrm{Thr}_{-6}$ of the peptide ligand and mutation in this C-terminal loop decreases the binding affinity drastically. ${ }^{27}$ Thus, from previous work ${ }^{11,12,14,24,27}$ together with the present data we conclude that some PDZ domains contain certain structural elements at their C-terminus, which have a direct effect on binding affinity. 
An appealing model is that such binding surfaces in PDZ domains not only increase affinity for the ligand but also the specificity. For example, the peptide residues at positions -6 to -8 of CRIPT appears not have a net positive energetic effect on the binding of PDZ3 ${ }^{15}$, but they might well have a negative effect on binding to other PDZ domains. In the case of PDZ3 from PSD-95, the $\alpha 3$-helix is likely to provide part of an extended binding surface and in this way increase the specificity toward its natural ligand, CRIPT.

\section{REFERENCES}

1. Nourry, C., Grant, S. G. N., and Borg, J.-P. (2003) PDZ Domain Proteins: Plug and Play! Sci. STKE 2003, re7.

2. Kim, E., Niethammer, M., Rothschild, A., Jan, Y. N., and Sheng, M. (1995) Clustering of Shaker-type $\mathrm{K}+$ channels by interaction with a family of membrane-associated guanylate kinases. Nature 378, 85-88.

3. Kornau, H. C., Schenker, L. T., Kennedy, M. B., and Seeburg, P. H. (1995) Domain interaction between NMDA receptor subunits and the postsynaptic density protein PSD-95. Science 269, 1737-1740.

4. Niethammer, M., Kim, E., and Sheng, M. (1996) Interaction between the C terminus of NMDA receptor subunits and multiple members of the PSD-95 family of membrane-associated guanylate kinases. J. Neurosci. 16, 2157-2163.

5. Jemth, P., and Gianni, S. (2007) PDZ domains: folding and binding. Biochemistry 46, 8701-8708.

6. Chi, C. N., Bach, A., Strømgaard, K., Gianni, S., and Jemth, P. (2012) Ligand binding by PDZ domains. BioFactors In press.

7. Wiedemann, U., Boisguerin, P., Leben, R., Leitner, D., Krause, G., Moelling, K., Volkmer-Engert, R., and Oschkinat, H. (2004) Quantification of PDZ Domain Specificity, Prediction of Ligand Affinity and Rational Design of Super-binding Peptides. J. Mol. Biol. 343, 703-718.

8. te Velthuis, A. J. W., Sakalis, P. A., Fowler, D. A., and Bagowski, C. P. (2011) Genome-Wide Analysis of PDZ Domain Binding Reveals Inherent Functional Overlap within the PDZ Interaction Network. PLoS ONE 6, e16047.

9. Gianni, S., Haq, S. R., Montemiglio, L. C., Jürgens, M. C., Engström, Å., Chi, C. N., Brunori, M., and Jemth, P. (2011) Sequence-specific Long Range Networks in PSD-95/Discs Large/ZO-1 (PDZ) Domains Tune Their Binding Selectivity. J. Biol. Chem. 286, 27167-27175. 
10. Fuentes, E. J., Der, C. J., and Lee, A. L. (2004) Ligand-dependent Dynamics and Intramolecular Signaling in a PDZ Domain. J. Mol. Biol. 335, 1105-1115.

11. Nomme, J., Fanning, A. S., Caffrey, M., Lye, M. F., Anderson, J. M., and Lavie, A. (2011) The Src Homology 3 Domain Is Required for Junctional Adhesion Molecule Binding to the Third PDZ Domain of the Scaffolding Protein ZO-1. J. Biol. Chem. 286, 43352-43360.

12. Pan, L., Chen, J., Yu, J., Yu, H., and Zhang, M. (2011) The Structure of the PDZ3-SH3-GuK Tandem of ZO-1 Protein Suggests a Supramodular Organization of the Membrane-associated Guanylate Kinase (MAGUK) Family Scaffold Protein Core. J. Biol. Chem. 286, 40069-40074.

13. Doyle, D. A., Lee, A., Lewis, J., Kim, E., Sheng, M., and MacKinnon, R. (1996) Crystal structures of a complexed and peptide-free membrane proteinbinding domain: molecular basis of peptide recognition by PDZ. Cell 85, 1067-1076.

14. Petit, C. M., Zhang, J., Sapienza, P. J., Fuentes, E. J., and Lee, A. L. (2009) Hidden dynamic allostery in a PDZ domain. Proc. Natl Acad. Sci. U. S. A. 106, 18249-18254.

15. Saro, D., Li, T., Rupasinghe, C., Paredes, A., Caspers, N., and Spaller, M. R. (2007) A Thermodynamic Ligand Binding Study of the Third PDZ Domain (PDZ3) from the Mammalian Neuronal Protein PSD-95. Biochemistry 46, 6340-6352.

16. Gianni, S., Engström, Å., Larsson, M., Calosci, N., Malatesta, F., Eklund, L., Ngang, C. C., Travaglini-Allocatelli, C., and Jemth, P. (2005) The kinetics of PDZ domain-ligand interactions and implications for the binding mechanism. J. Biol. Chem. 280, 34805-34812.

17. Chi, C. N., Elfström, L., Shi, Y., Snäll, T., Engström, Å., and Jemth, P. (2008) Reassessing a sparse energetic network within a single protein domain. Proc. Natl. Acad. Sci. U. S. A. 105, 4679-4684.

18. Chi, C. N., Engström, Å., Gianni, S., Larsson, M., and Jemth, P. (2006) Two conserved residues govern the salt and $\mathrm{pH}$ dependencies of the binding reaction of a PDZ domain. J. Biol. Chem. 281, 36811-36818.

19. Niethammer, M., Valtschanoff, J. G., Kapoor, T. M., Allison, D. W., Weinberg, T. M., Craig, A. M., and Sheng, M. (1998) CRIPT, a novel postsynaptic protein that binds to the third PDZ domain of PSD-95/SAP90. Neuron 20, 693-707.

20. Delaglio, F., Grzesiek, S., Vuister, G. W., Zhu, G., Pfeifer, J., and Bax, A. (1995) NMRPipe: a multidimensional spectral processing system based on UNIX pipes. J. Biomol. NMR 6, 277-293.

21. Malatesta, F. (2005) The study of bimolecular reactions under non-pseudofirst order conditions. Biophys. Chem. 116, 251-256.

22. Wiseman, T., Williston, S., Brandts, J. F., and Lin, L. N. (1989) Rapid measurement of binding constants and heats of binding using a new titration calorimeter. Anal. Biochem. 179, 131-137.

23. Zhang, J., Petit, C. M., King, D. S., and Lee, A. L. (2011) Phosphorylation of a PDZ Domain Extension Modulates Binding Affinity and Interdomain Interactions in Postsynaptic Density-95 (PSD-95) Protein, a Membraneassociated Guanylate Kinase (MAGUK). J. Biol. Chem. 286, 41776-41785.

24. Mostarda, S., Gfeller, D., and Rao, F. (2012) Beyond the Binding Site: The Role of the beta2 - beta3 Loop and Extra-Domain Structures in PDZ Domains. PLoS Comput. Biol. 8, e1002429. 
25. Wang, C., Pan, L., Chen, J., and Zhang, M. (2010) Extensions of PDZ domains as important structural and functional elements. Protein \& Cell 1, 737-751.

26. Bhattacharya, S., Dai, Z., Li, J., Baxter, S., Callaway, D. J. E., Cowburn, D., and $\mathrm{Bu}, \mathrm{Z}$. (2010) A Conformational Switch in the Scaffolding Protein NHERF1 Controls Autoinhibition and Complex Formation. J. Biol. Chem. 285, 9981-9994.

27. Charbonnier, S., Nominé, Y., Ramírez, J., Luck, K., Chapelle, A., Stote, R. H., Travé, G., Kieffer, B., and Atkinson, R. A. (2011) The Structural and Dynamic Response of MAGI-1 PDZ1 with Noncanonical Domain Boundaries to the Binding of Human Papillomavirus E6. J. Mol. Biol. 406, 745-763. 


\section{Tables}

Table 1: Binding constants for the interaction between dansylated peptide, DYKQTSV and wild-type and mutant PDZ3. $k_{\mathrm{on}}$ and $k_{\text {off }}$ values were obtained from fitting Eqs. 2 and 3, respectively, to the $k_{\mathrm{obs}}$ values from pre-equilibrium ligand binding stopped-flow measurements. Errors in $k_{\text {on }}$ and $k_{\text {off }}$ are fitting errors, while the other errors are propagated fitting errors.

\begin{tabular}{|l|c|l|l|c|}
\hline PDZ & $\begin{array}{c}k_{\text {off }} \\
\left(\mathrm{s}^{-1}\right)\end{array}$ & $\begin{array}{c}k_{\text {on }} \\
\left(\mu \mathrm{Ms}^{-1}\right)\end{array}$ & $\begin{array}{c}K_{\mathrm{D}}\left(k_{\text {off }} / k_{\text {on }}\right) \\
(\mu \mathrm{M})\end{array}$ & $\begin{array}{c}\Delta \Delta G \\
(\mathrm{kcal} / \mathrm{mol})\end{array}$ \\
\hline PDZ3 & $1.6 \pm 0.20$ & $11 \pm 0.20$ & $0.15 \pm 0.02$ & \\
\hline PDZ3 $\Delta \alpha 3$ & $150 \pm 40$ & $13 \pm 3$ & $11 \pm 4$ & $-2.4 \pm 0.4$ \\
\hline Y397E & $40 \pm 2$ & $8.0 \pm 0.3$ & $5 \pm 0.3$ & $-2.0 \pm 0.15$ \\
\hline R399A & $6.0 \pm 0.3$ & $10 \pm 1$ & $0.6 \pm 0.07$ & $-0.8 \pm 0.2$ \\
\hline F400A & $50 \pm 1.0$ & $19 \pm 3$ & $2.7 \pm 0.4$ & $-1.6 \pm 0.2$ \\
\hline
\end{tabular}

Table 2: ITC binding data for PDZ-peptide interactions. n.d., not detectable.

\begin{tabular}{|c|c|c|c|c|c|c|c|c|}
\hline & \multicolumn{3}{|c|}{ YKQTSV } & \multicolumn{3}{c|}{ KQTSV } \\
\hline PDZ & $\begin{array}{c}\Delta H \\
(\mathrm{kcal} / \mathrm{mol})\end{array}$ & $\begin{array}{c}-T \Delta S \\
(\mathrm{kcal} / \mathrm{mol})\end{array}$ & $\begin{array}{c}K_{\mathrm{D}} \\
(\mu \mathrm{M})\end{array}$ & $n$ & $\begin{array}{c}\Delta \mathrm{H} \\
(\mathrm{kcal} / \mathrm{mol})\end{array}$ & $\begin{array}{c}-T \Delta S \\
(\mathrm{kcal} / \mathrm{mol})\end{array}$ & $K_{\mathrm{D}}(\mu \mathrm{M})$ & $n$ \\
\hline PDZ3 & $-10 \pm 1$ & $1.9 \pm 0.2$ & $1 \pm 0.1$ & $0.8 \pm 0.1$ & $-4.0 \pm 0.1$ & $-3.8 \pm 0.4$ & $2.0 \pm 0.3$ & $1 \pm 0.1$ \\
\hline $\begin{array}{c}\text { PDZ3 } \\
\Delta \alpha 3\end{array}$ & $-3.4 \pm 0.6$ & $-3.7 \pm 0.6$ & $6 \pm 0.2$ & $0.9 \pm 0.1$ & n.d. & n.d. & n.d. & n.d. \\
\hline
\end{tabular}


Figure legends

Figure 1. Structure of PDZ3 in complex with a peptide ligand, TKNYKQTSV. PDZ3 with CRIPT peptide adapted from ref. ${ }^{24}$ The helix $\alpha 3$ and the $\mathrm{Tyr}_{397}$ side chain are shown in blue. The peptide residues are colored purple with the amide nitrogens in blue. The numbering of peptide ligand residues is according to the usual convention, starting from 0 at the C-terminus and then $-1,-2$ etc. This is one of several structures from an $\mathrm{MD}$ simulation $^{24}$ and not a representative average structure. However, it suggests that both $\mathrm{Tyr}_{397}$ and $\mathrm{Phe}_{400}$ may form transient interactions with $\mathrm{Tyr}_{-5}$ of the peptide ligand. The figure was drawn in PyMOL (The PyMOL Molecular Graphics System, DeLano Scientific, LLC).

Figure $2 .{ }^{1} \mathrm{H}-{ }^{15} \mathrm{~N}$ HSQC spectra of the peptide GSKNYKQTSV in complex with PDZ3 and PDZ3 $\triangle$ a3. A) The apo-peptide is shown in black, the peptide in complex with PDZ3 is shown in blue ( $>99 \%$ saturation) and the peptide in complex with PDZ3 $\Delta \alpha 3$ is shown in red ( $>98 \%$ saturation). The nomenclature of the residues is as follows: a_V0 is the C-terminal valine in the apo-peptide, d_V0 is the C-terminal valine in the peptide in complex with PDZ3 $\Delta \alpha 3$, and V0 the C-terminal valine in the peptide in complex with PDZ3. B) HSQC spectrum of peptide at $0 \%$ (black), $89 \%$ (green) and $>99 \%$ (blue) saturation of PDZ3. Note that apo-peptide spectrum in A) was recorded at $277 \mathrm{~K}$ whereas the one in B) was recorded at $283 \mathrm{~K}$, hence the slightly different appearance. As expected more peaks are present at the lower temperature. 
Figure 3. Chemical shift differences upon peptide binding. ${ }^{13} \mathrm{C} /{ }^{1} \mathrm{H}$ chemical shift perturbation for peptide side-chains upon binding to either PDZ3 (blue) or with PDZ3 $\Delta \alpha 3$ (red), respectively. The inset shows the ${ }^{15} \mathrm{~N} /{ }^{1} \mathrm{H}$ chemical shift difference of the backbone amides upon binding to PDZ3 (blue) or PDZ3 $\Delta \alpha 3$ (red), respectively. The chemical shift perturbations were calculated as $\left(\Delta \varpi_{H}^{2}+\left(\Delta \varpi_{C} \times 0.25\right)^{2}\right)^{0.5}$ and $\left(\Delta \varpi_{\mathrm{H}}^{2}+\left(\Delta \varpi_{\mathrm{N}} \times 0.1\right)^{2}\right)^{0.5}$, respectively. Assignments of the type HB1 and HB2 do no indicate stereospecific assignments but is merely a way of labeling protons with distinct chemical shifts that are bound to the same carbon.

Fig. 4. NOESY-HSQC spectra of Lys-4 and $\mathbf{T y r}_{-5}$. Intra and inter-molecular NOEs involving HE of $\operatorname{Tyr}_{-5}(\mathrm{I}-\mathrm{II})$ and $\mathrm{HG} 2$ of $\mathrm{Val}_{0}$ (III-IV) of the peptide $(290 \mu \mathrm{M}$ or 150 $\mu \mathrm{M}$ ) saturated with PDZ3 (I, III) or PDZ3 $\Delta \alpha 3$ (II, IV), respectively, as well as HA of Lys-4 of peptide in complex with PDZ3 (V). For clarity, the peaks in panels showing peptide in complex with PDZ3 are colored blue and those for PDZ3 $\Delta \alpha 3$ are colored red. Assignments of intra-molecular NOEs are shown and unassigned inter-molecular NOEs to the PDZ domain are highlighted with an arrow. Absence of putative intramolecular NOEs are indicated with a cross. Note the disappearance of certain NOEs when helix $\alpha 3$ is deleted (I vs. II and III vs. IV, respectively).

Figure 5. Thermodynamics of the PDZ-peptide interaction. Isothermal titration calorimetric experiments of A) PDZ3 with YKQTSV and B) PDZ3 with KQTSV, respectively. Upper panels: Raw ITC data. Lower panels: Integrated peak areas (black squares) and fit with the one-binding-site model of ORIGIN provided by MicroCal (continuous line). The concentrations used in these experiments were: A) $8 \mu \mathrm{M}$ PDZ3 with $0.12 \mathrm{mM}$ YKQTSV and B) $13 \mu \mathrm{M}$ PDZ3 with $0.18 \mathrm{mM}$ KQTSV. C) Plot of the 
$\Delta G$ (black bars), $\Delta H$ (white bars) and $-T \Delta S$ (grey bars) derived from the data and also reported in Table 2.

Fig. 6. Equilibrium displacement experiments. A complex of D-YKQTSV (3 $\mu \mathrm{M})$ and either A) PDZ3 or B) PDZ3 $\triangle \alpha 3$ was dissociated with YKQTSV or KQTSV in separate experiments. If the affinity for D-YKQTSV $\left(K_{\mathrm{D} 1}\right)$ is known the affinity for the unlabeled peptides $\left(K_{\mathrm{D} 2}\right)$ can be estimated using Eq. 5 as described in Materials. $K_{\mathrm{D} 2}$ values were $1.0 \pm 0.3 \mu \mathrm{M}$ and $4.3 \pm 0.3 \mu \mathrm{M}$ for PDZ3 with YKQTSV and KQTSV, respectively. However, the low affinity of PDZ3 $\Delta \alpha 3$ for both YKQTSV $(43 \pm 36 \mu \mathrm{M})$ and in particular KQTSV $(360 \pm 320 \mu \mathrm{M})$ yielded an error in the analysis that is on the same order as the value, precluding a quantitative analysis of the interaction and the calculation of a reliable coupling free energy between $\alpha 3$ and $\mathrm{Tyr}_{-5}$. These experiments were performed in the stopped-flow fluorimeter and normalized kinetic endpoints are plotted on the y-axes.

Figure 7. Pre-equilibrium binding data for PDZ3 and mutants. A) Observed rate constants for the interaction of PDZ and peptide plotted against increasing concentration of the dansylated (D) peptide D-YKQTSV. B) Observed rate constants for the displacement of the PDZ3/D-YKQTSV complex plotted against increasing concentration YKQTSV. The rate constant at the high concentration of unlabeled peptide is equal to the off-rate constant in the interaction of PDZ3 and D-YKQTSV. 


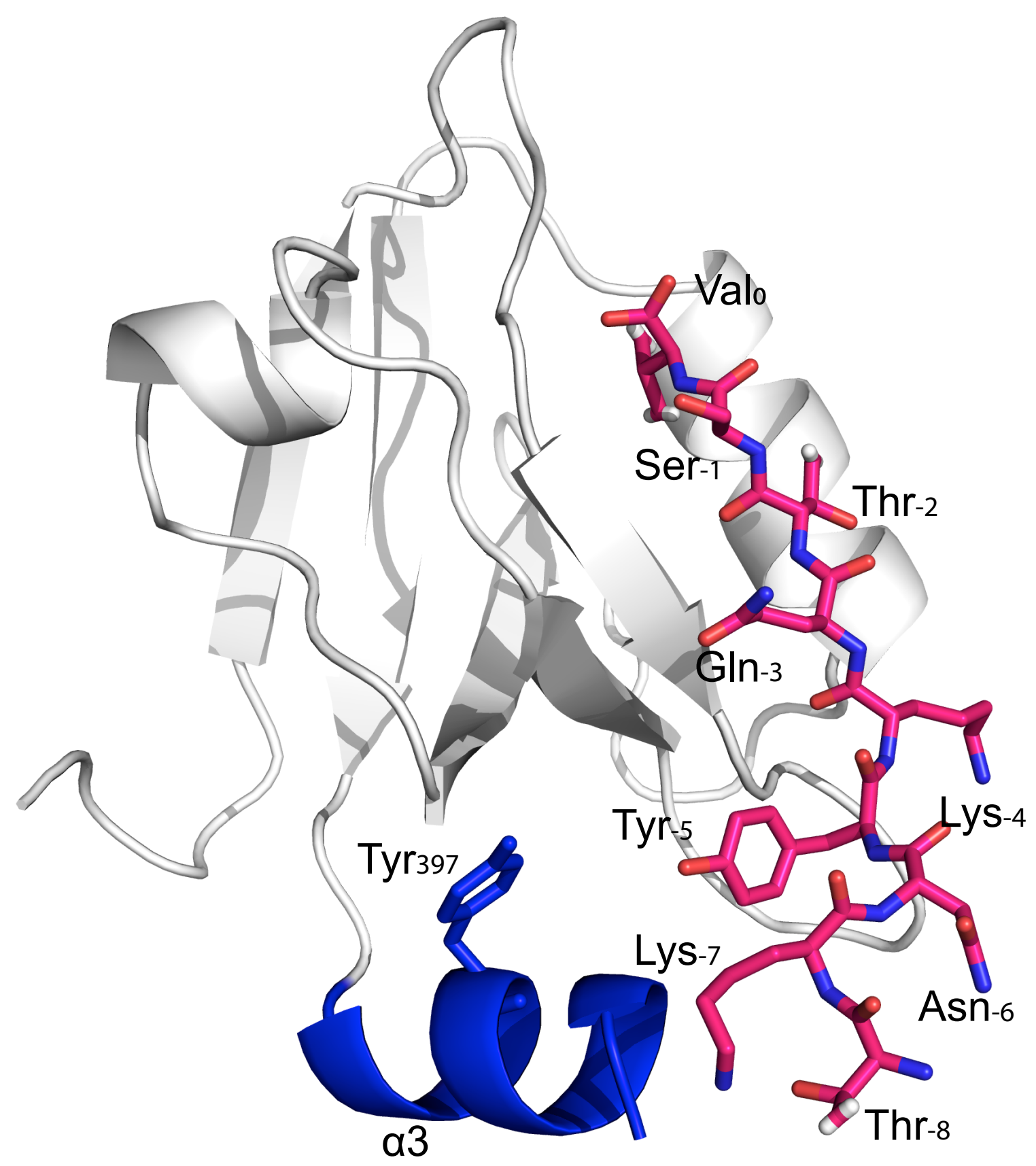


Fig. 2

A 9.0

8.5

8.0

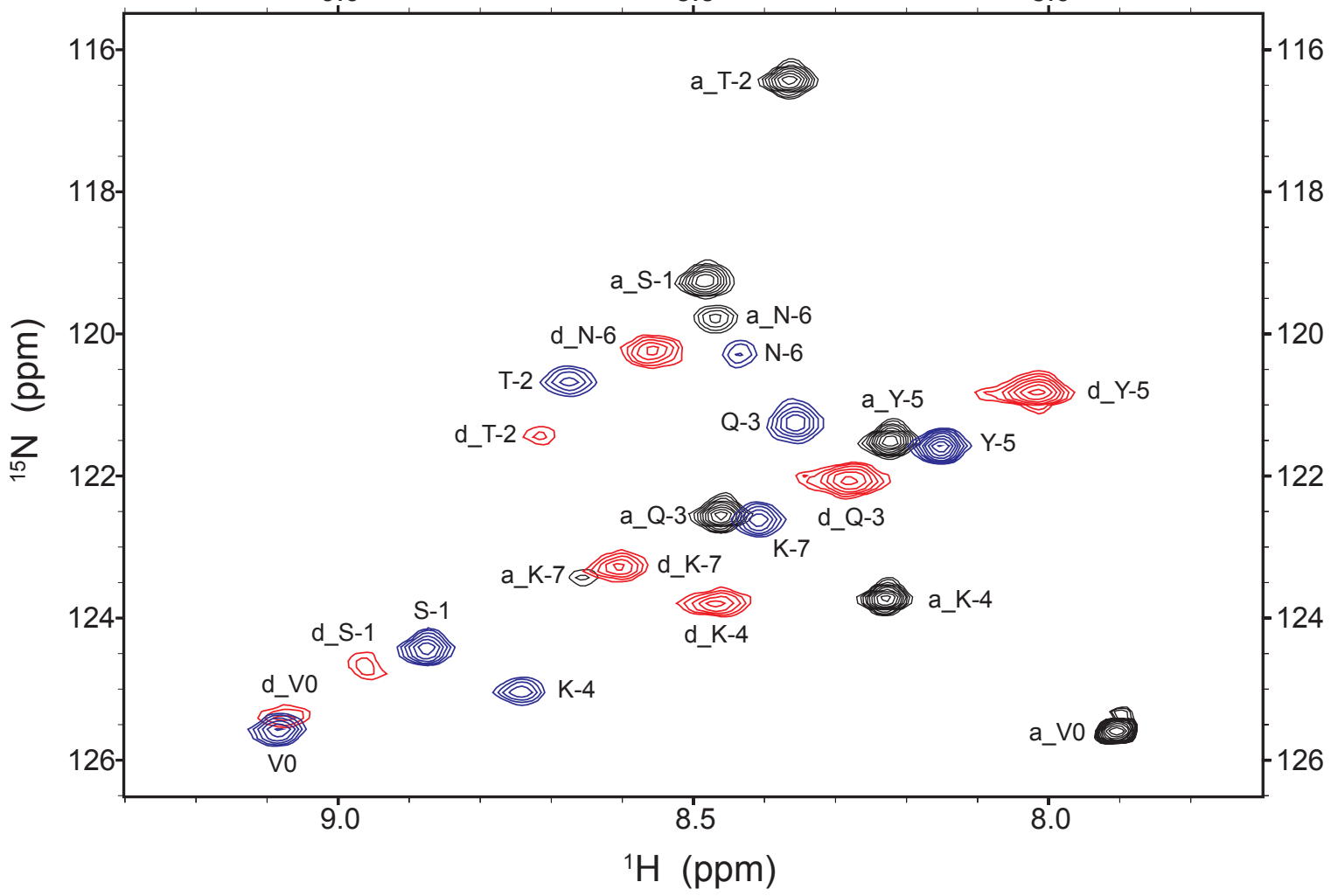

B

9.0

8.5

8.0

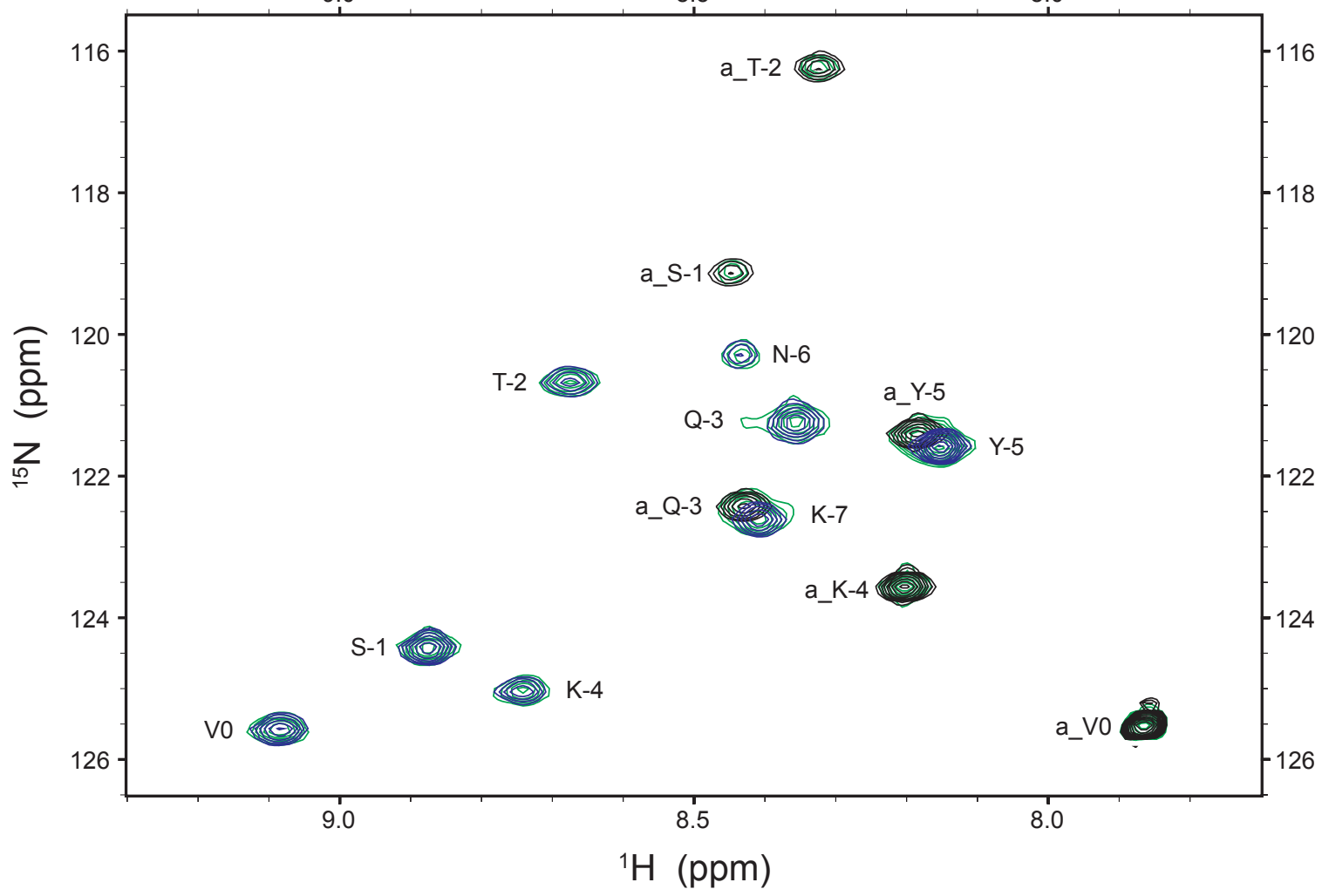


Fig. 3

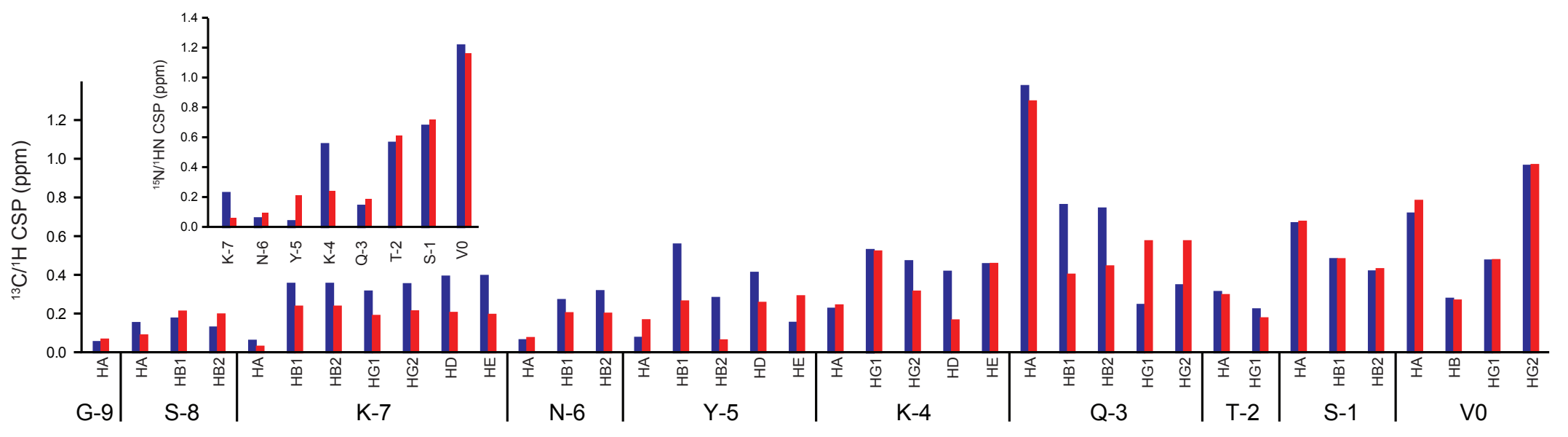




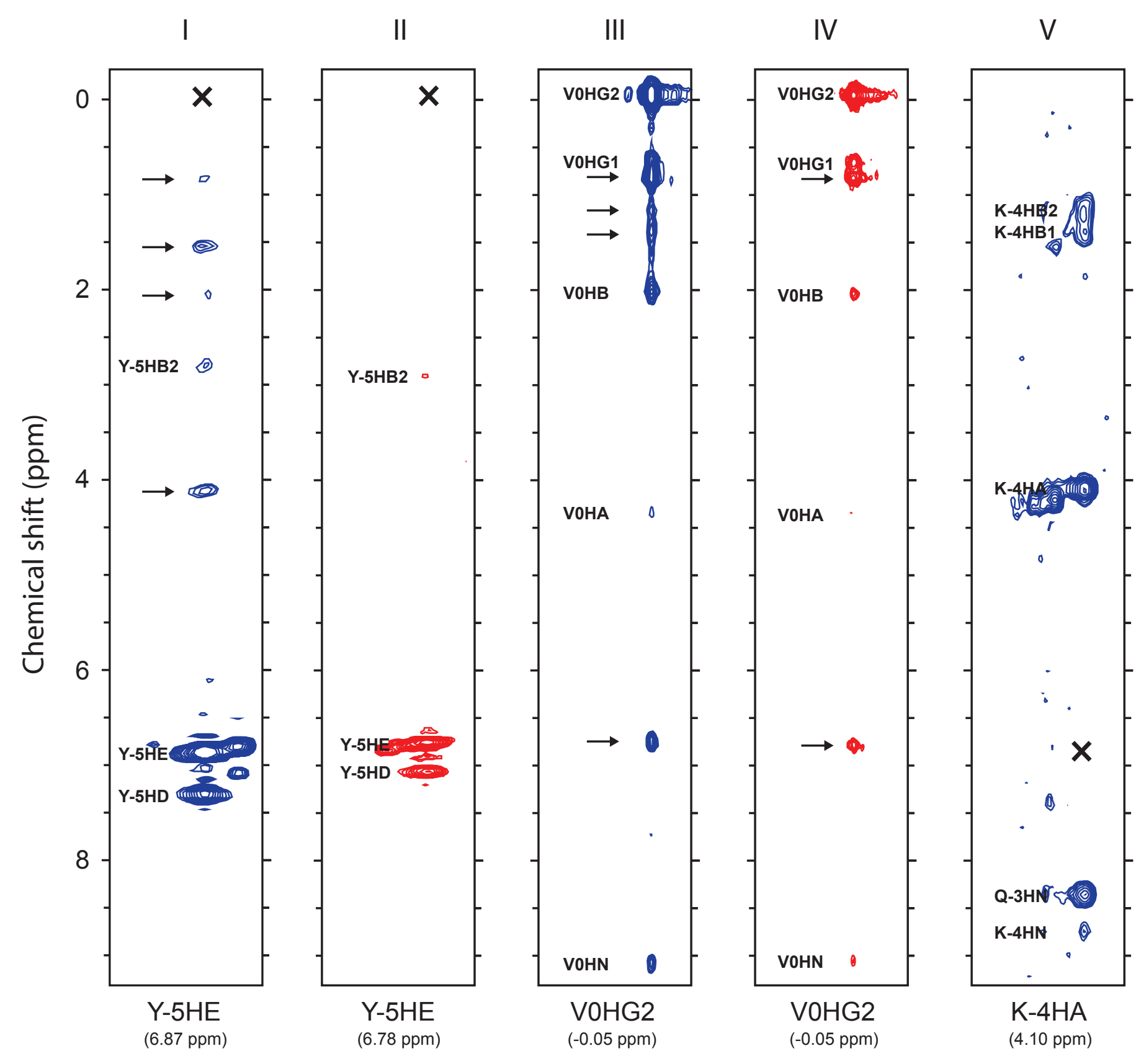



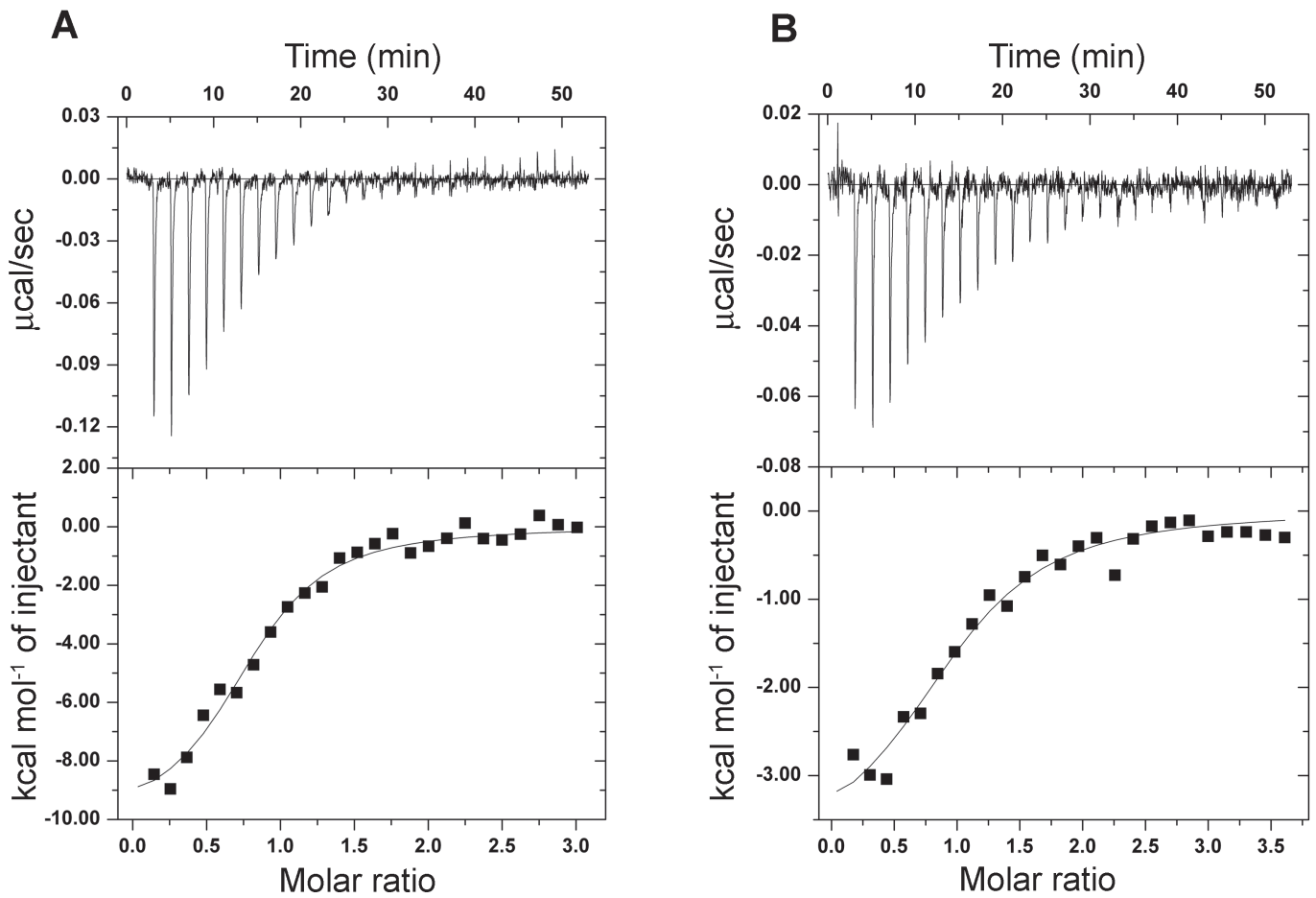

C

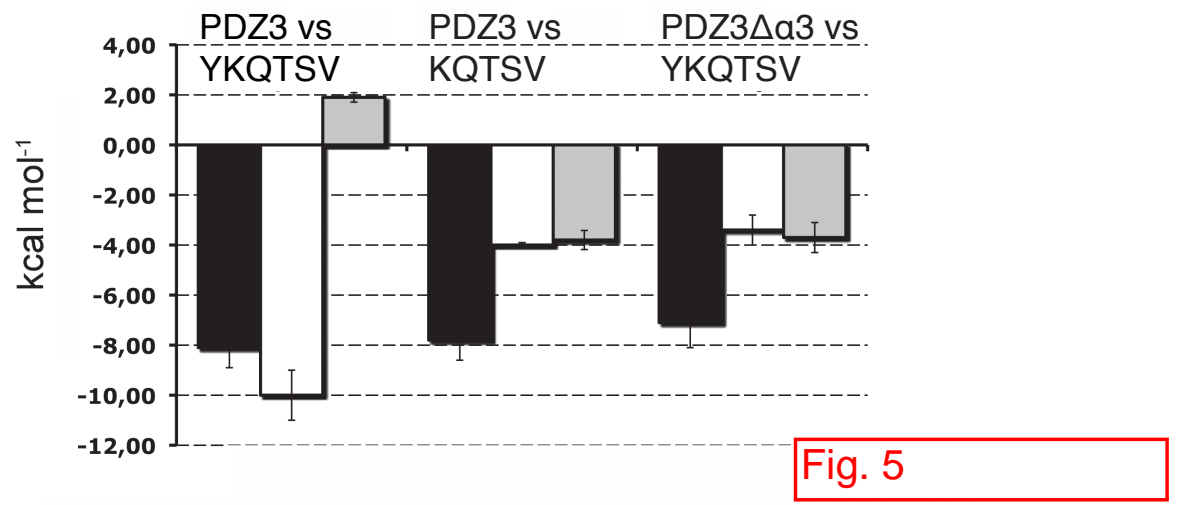




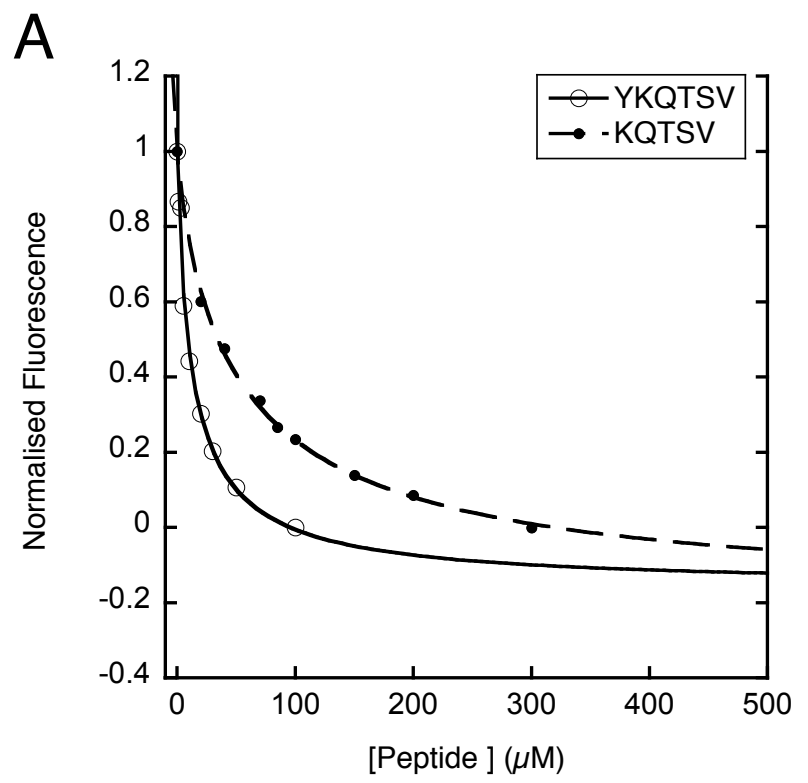

Fig. 6

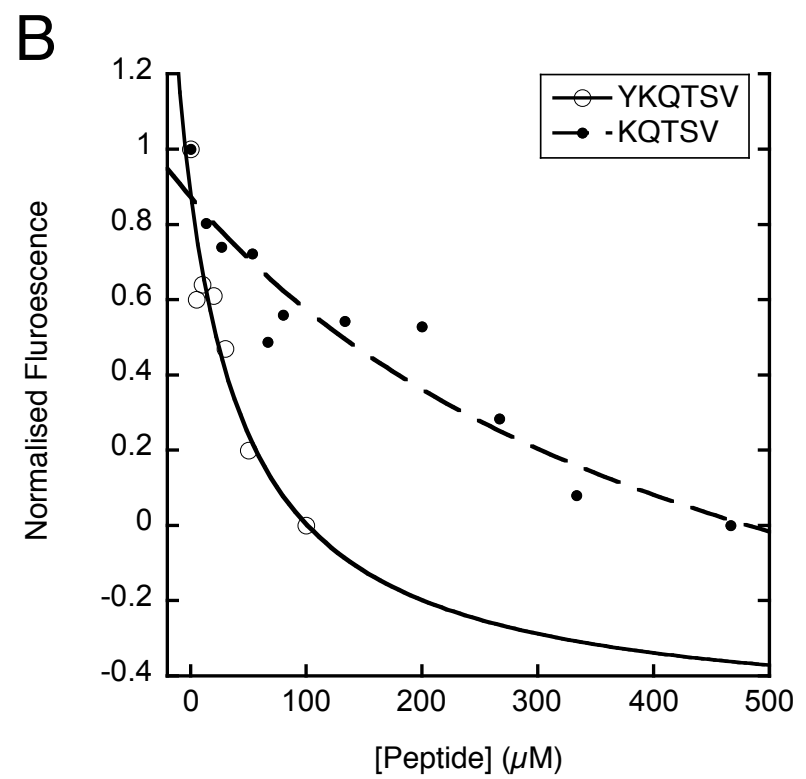


Fig. 7

A

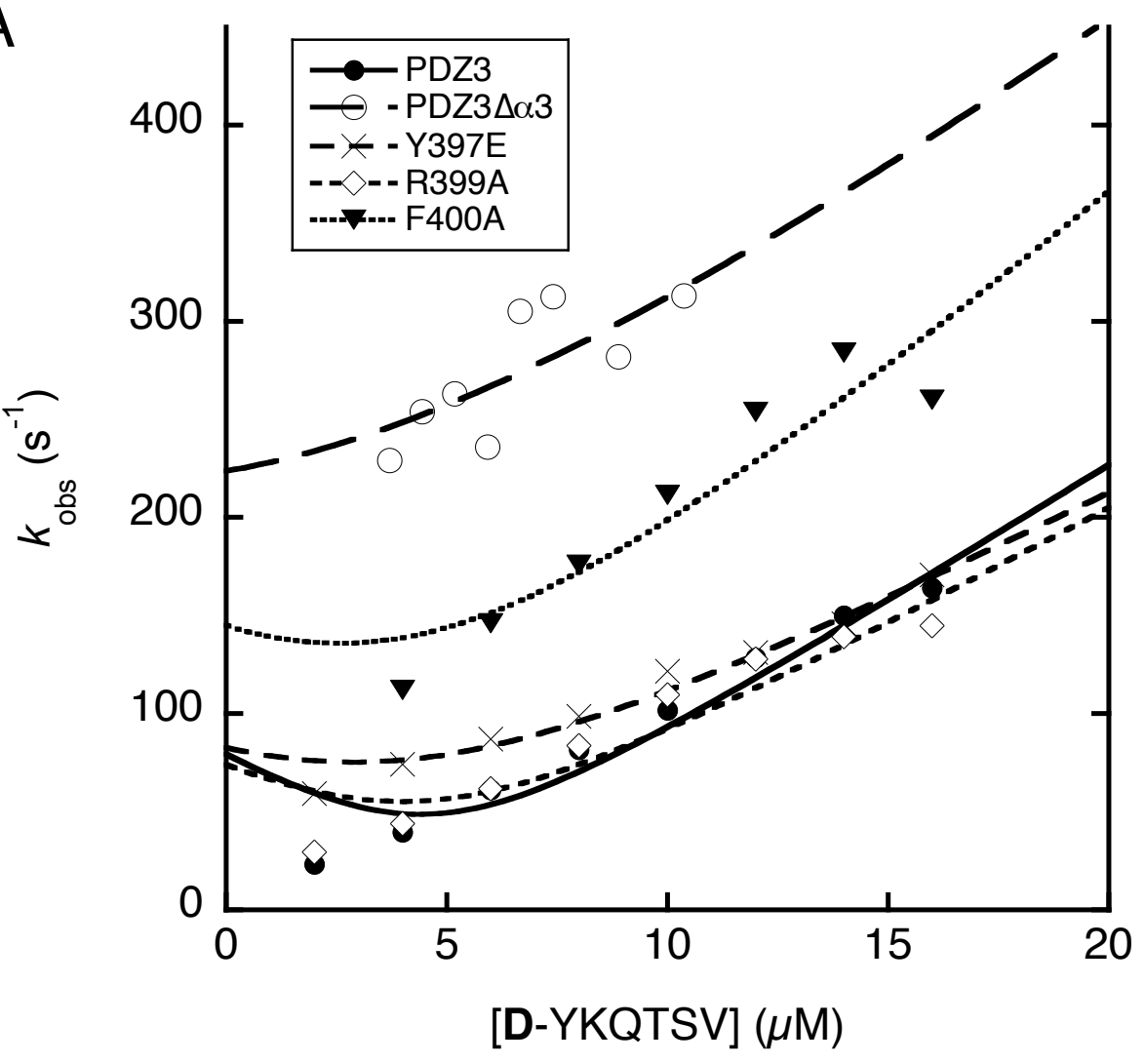

B

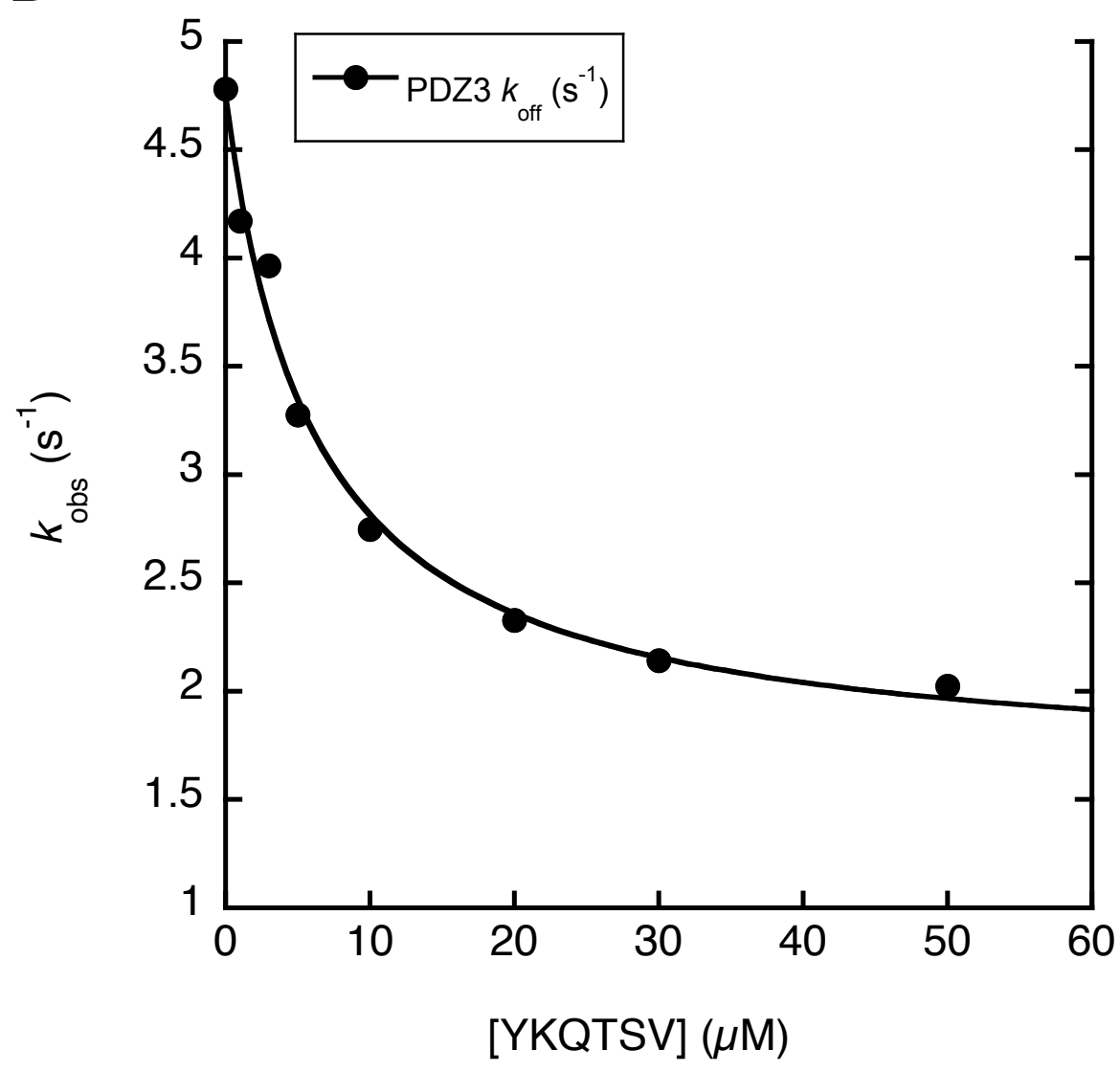




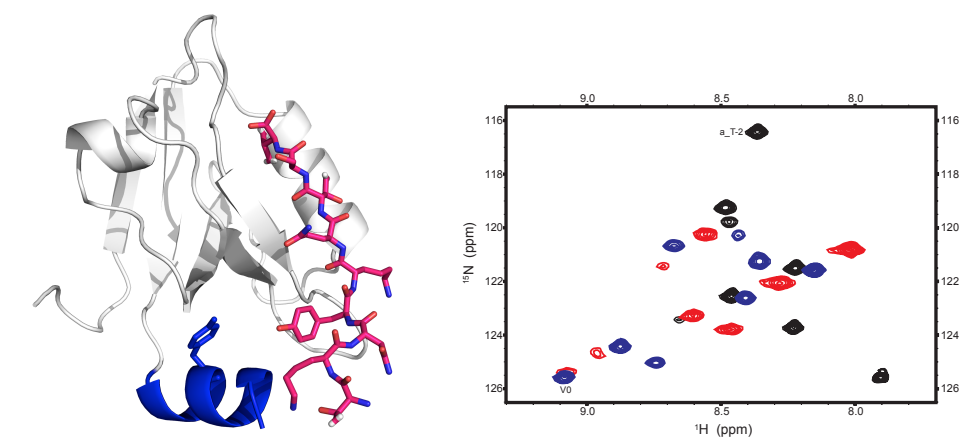

